\title{
PERBANDINGAN POTENSI FOTO PROTEKTOR EKSTRAK ETANOL BUAH TAKOKAK DENGAN KRIM EKSTRAK ETANOL BUAH TAKOKAK (Solanum torvum Swartz) SECARA IN VITRO DENGAN SPEKTROFOTOMETRI UV-VIS
}

\section{THE COMPARISON OF PHOTO PROTECTOR POTENTIAL BETWEEN EXTRACT ETAHANOLIC TAKOKAK FLESH FRUIT WITH CREAM CONTAINS EXTRACT ETHANOLIC TAKOKAK FLESH FRUIT (Solanum torvum Swartz) IN VITRO BY SPECTROPHOTOMETRY UV-VIS}

\author{
Debby Juliadi ${ }^{1 *}$, RR. Asih Juanita ${ }^{1}$ \\ ${ }^{1}$ Fakultas Farmasi Universitas Mahasaraswati Denpasar \\ ${ }^{*}$ Corresponding Author Email: debby.eternity46@gmail.com \\ DOI: http://dx.doi.org/10.47653/farm.v7i1.153
}

\begin{abstract}
ABSTRAK
Pengujian potensi ekstrak buah takokak dilakukan dengan menggunakan spektrofotometri UV-Vis. Ekstraksi menggunakan metode Maserasi kemudian dipekatkan dengan rotary evaporator. Ekstrak kemusian di skrining fitokimia untuk mengetahui adanya senyawa tanin dan flavonoid kemudian dibuat dalam bentuk sediaan krim serta diuji mutu fisiknya baik dari homogenitas, $\mathrm{pH}$, tipe emulsi dan stabilitas krim. Ekstrak buah takokak dan krim ekstrak buah takokak diukur serapannya setiap $5 \mathrm{~nm}$ pada rentang panjang gelombang $290-400 \mathrm{~nm}$. Dari hasil penelitian diperoleh ekstrak dan krim ekstrak buah takokak hanya mampu memberikan nilai SPF minimal yaitu 2,199 pada ekstrak dengan konsentrasi 400 ppm, 2,615 pada ekstrak dengan konsentrasi 500 ppm dan 2,118 pada krim dengan konsentrasi 500 ppm, bila dilihat dari persentase eritema baik ekstrak ataupun krim belum memberikan perlindungan dari paparan sinar UVB, dilihat dari persentase transmisi pigmentasi baik ekstrak maupun krim memiliki kemampuan extra protection yang artinya ekstrak dan sediaan tersebut mampu menyerap hingga 85\% sinar UVA.
\end{abstract}

Kata Kunci: Buah Takokak, Tanin, Flavonoid, Potensi Foto Protektor

\begin{abstract}
The testing of the potential of takokak fruit extract was carried out in vitro using UV-Vis spectrophotometry. extract made by maceration then concentrated with a rotary evaporator. The extract obtained was carried out phytochemical screening to determine the composition of tannins and flavonoids. The extract was then made in cream dosage form with physical requirements, both from homogeneity, $\mathrm{pH}$, emulsion type and cream credentials. Takokak fruit extract and takokak fruit extract cream were determined to absorb every $5 \mathrm{~nm}$ in the wavelength range of 290-400 nm. From the results of research obtained from extracts and creams of takokak fruit, it was only able to provide a minimum SPF value of 2.199 in extracts with concentrations of 400 ppm, 2.615 in extracts with concentrations of $500 \mathrm{ppm}$ and 2.118 in creams with a concentration of $500 \mathrm{ppm}$, can be seen from erythema results in protection from light exposure UVB (changing erythema), approved in view of the contribution of pigmentation transmission to both extracts and creams having the extra protective ability, which means the extracts and preparations can absorb up to $85 \%$ of UVA rays.
\end{abstract}

Keywords: Takokak Flesh Fruit, Tannins, Flavonoids, Photo Protector Potential

\section{PENDAHULUAN}

Sinar matahari sangat dibutuhkan oleh semua makhluk hidup untuk kelangsungan hidupnya. Di satu pihak, sinar matahari diperlukan oleh manusia sebagai sumber energi dan penyehat kulit dan tulang, misalnya dalam pembentukan vitamin $D$ dan pro-vitamin $D$ yang mencegah penyakit polio atau riketsia namun sinar matahari yang sampai di permukaan mempunyai dampak negatif terhadap kulit yaitu sinar UV A dan UV B (Ismail 2013). Radiasi ultraviolet (UV) didefinisikan sebagai bagian dari radiasi elektromagnetik yang berada diantara sinar- $X$ dan sinar tampak, dengan panjang gelombang 200-400nm. Radiasi ultraviolet ini terdiri dari 3 
kategori berdasarkan panjang gelombangnya, yaitu: radiasi UV-A yang berada pada panjang gelombang $320-400 \mathrm{~nm}$, radiasi ini yang paling bertanggung jawab terhadap penyamakan langsung atau penggelapan kulit karena kelebihan produksi melanin dari kulit ari. Kemudian radiasi UV-B yang berada pada panjang gelombang 280-320 nm. Radiasi UV$B$ dikenal sebagai sinar yang mampu menyebabkan kulit terbakar 1000 kali daripada sinar UV-A. Selanjutnya sinar UV-C yang berkisar antara 200-280 $\mathrm{nm}$, radiasi ini disaring oleh lapisan ozon stratosfer sehingga lebih tidak efektif dan tidak berbahaya bagi kulit (Donglikar dan Deore, 2016).

Sinar ultraviolet dari matahari dapat merusak kulit seperti kemerahan, pendarahan, penuaan dan kanker kulit. Kulit memiliki sistem perlindungan alami terhadap efek sinar matahari, tetapi tidak efektif untuk menahan paparan sinar matahari yang berlebih, oleh karena itu diperlukan pelindung tambahan menggunakan krim foto protektor. Salah satu produk kosmetik yang banyak digunakan yaitu krim foto protektor. Efektivitas dari krim foto protektor biasanya dinyatakan dengan nilai SPF (Sun Protection Factor). Nilai SPF semakin besar maka semakin besar perlindungan yang diberikan oleh produk krim foto protektor tersebut.

Penggunaan bahan-bahan alam sebagai obat tradisional maupun kosmetik tradisional di Indonesia sudah di kenal sejak berabad-abad lalu. Dewasa ini, penggunaan senyawa bahan alam telah diterima secara luas hampir diseluruh dunia. Kesempatan untuk mengeksplorasi kekayaan alam khususnya alam Indonesia masih sangat besar peluangnya. Diluar sana, masih banyak terdapat tumbuhan atau organisme lain yang belum dimanfaatkan secara optimal sebagai konversi obat modern maupun kosmetik. Buah takokak (Solanum torvum), atau dibeberapa daerah dikenal sebagai terong cepoka merupakan salah satu tumbuhan yang belum dimanfaatkan secara maksimal. Buah takokak umumnya hanya digunakan sebagai pelengkap dalam menyajikan makanan saja, bahkan dibuang begitu saja. Eksplorasi ini penting untuk dilakukan karena sangat bermanfaat untuk pengembangan industri kosmetik. Buah takokak diketahui memiliki banyak senyawa yang dapat dimanfaatkan sebagai bahan dasar kosmetik. Solanum torvum, secara ekstensif telah dieksplorasi kandungan kimianya. Tanaman ini merupakan sumber alkaloid, flavonoid, saponin, tanin dan glikosida yang sangat baik (Yousaf, Wang, dan Baydoun 2013). Komponen-komponen bioaktif pada suatu bahan, khususnya tanaman takokak dapat berasal dari senyawa fenolik dan senyawa non fenolik.

Senyawa bahan alam yang sudah dimanfaatkan sebagai agen pelindung dari sinar ultraviolet yaitu Vitamin C, Vitamin E dan ß-karoten. Senyawa bioaktif fenolik dapat berperan sebagai bahan aktif krim foto protektor dan dapat meningkatkan nilai SPF pada krim foto protektor atau foto protektor. Senyawa fenolik khususnya golongan flavonoid mempunyai potensi sebagai foto protektor karena adanya gugus kromofor yang mampu menyerap sinar UV sehingga mengurangi intensitasnya pada kulit (Whenny, Rusli, dan Laode Rijai, 2016).

Beberapa komponen bioaktif yang terdapat dalam buah takokak yang termasuk senyawa fenolik adalah fenol, flavonoid termasuk antosianin dan tanin. Sementara itu, beberapa komponen bioaktif yang termasuk senyawa non fenolik adalah asam askorbat (vitamin C), alkaloid, terpenoid/steroid, dan saponin. Meskipun sun block dengan bahan sintetis seperti oxibenzon, seng oksida, titanium dioksida memiliki kemampuan tindakan perlindungan terhadap sinar matahari yang cepat, tetapi secara bersamaan memiliki potensi risiko yang terkait dengannya. Hasil CDC (Centers for Disease Control and Prevention) yang diadakan tahun 2007 menyatakan bahwa seorang ibu dengan kadar oxibenzon yang tinggi dalam tubuh cenderung melahirkan bayi dengan berat badan rendah. Menurut Therapeutic Goods Administration ada bukti bahwa seng oksidan dan titanium dioksida dapat menginduksi pembentukan radikal bebas dan dapat merusak sel normal (fotomutagenik seng dioksid). Maka dari itu, penggunaan bahan-bahan alam sebagai sediaan tabir surya sangat di sarankan karena tidak memicu reaksi alergi dan efek komedogenik. Selain itu konstituen herbal dapat dengan mudah di formulasikan menjadi suatu sediaan (Kulkarni, dkk. 2014).

\section{METODE PENELITIAN}

Penelitian ini merupakan eksperimental yang dilakukan di Laboratorium Fakultas Farmasi Universitas Mahasaraswati Denpasar. Penelitian ini dilakukan untuk mengetahui nilai Sun Protection Factor (SPF) dari sediaan krim yang mengandung ekstrak etanol buah 
takokak (Solanum torvum Swartz) dan perbandingannya dengan ekstrak melalui uji spektrofotometri UV-Vis.

\section{Bahan}

Bahan yang digunakan dalam penelitian ini yaitu, buah takokak (Solanum torvum Swartz) yang diperoleh dari Desa Mungsengan Kintamani, Kabupaten Bangli yang telah dideterminasi di LIPI Balai Konservasi Tumbuhan Kebun Raya "Eka Karya" BedugulBali, Etanol 70\%, aquadest, serbuk Magnesium, $\mathrm{HCl}$ pekat, $\mathrm{FeCl} 10 \%$, asam stearat, gliserin, setil alkohol, trietanolamin, nipagin.

\section{Alat}

Alat yang digunakan dalam penelitian ini yaitu, timbangan analitik (Acis AD-2100H), blender (Philips), Rotary Evaporator, Spektrofotometer UV-Vis double bean (Mapada), kertas saring, batang pengaduk, cawan porselen, thermometer, mortir dan stamper, penangas air, tabung reaksi (Pyrex), gelas ukur (Pyrex), labu ukur $100 \mathrm{~mL}$, corong kaca (Pyrex), pipet tetes.

\section{Pembuatan Ekstrak}

Pembuatan ekstrak dilakukan dengan metode maserasi atau perendaman. Buah takokak segar yang sebelumnya telah dibersihkan dengan air dan ditiriskan, kemudian dirajang dan dikeringkan pada sinar matahari. Buah takokak yang sudah kering diblender hingga terbentuk serbuk kasar. Ekstraksi maserasi 250 gram serbuk buah takokak dilakukan dalam wadah kaca tertutup selama 3 x 24 jam menggunakan pelarut etanol. Pemisahan residu dan filtrat dilakukan setiap $1 \times 24$ jam diiringi penggantian pelarut yang sama sehingga diperoleh filtrat I, II dan
III. Filtrat dikumpulkan dan dipekatkan dengan penguap berputar vakum pada suhu $45^{\circ} \mathrm{C}$ hingga diperoleh ekstrak kental. Ekstrak yang diperoleh kemudian ditimbang untuk mengetahui bobot ekstrak (Hamsidi, Ikawati, dan Zaeni 2014).

\section{Skrining Flavonoid dan Tanin}

Sebanyak 1 gram ekstrak ditambahkan $100 \mathrm{~mL}$ air panas, kemudian dididihkan selama 15 menit, lalu disaring. Sebanyak $5 \mathrm{~mL}$ filtrat yang diperoleh ditambahkan serbuk magnesium, amil alkohol dan $2 \mathrm{~mL}$ campuran alkohol-asam klorida (1:1). Kemudian dibiarkan memisah dan diamati warna yang terbentuk pada lapisan amil alkohol. Apabila terbentuk warna merah, kuning, atau jingga pada lapisan amil alkohol menunjukkan adanya golongan senyawa flavonoid (Hidayati dan Nofianti, 2014). Pengujian tanin dilakukan dengan ditimbang ekstrak kental sebanyak $40 \mathrm{mg}$ lalu dilarutkan dalam air. Sebanyak $2 \mathrm{~mL}$ ekstrak ditambahkan $1 \mathrm{~mL} \mathrm{FeCl} \mathrm{10 \% .} \mathrm{Reaksi} \mathrm{positif}$ tanin ditunjukan dengan adanya perubahan warna menjadi biru tua, biru kehitaman, atau hitam kehijauan. (Sa'adah, 2010).

\section{Uji Potensi Foto Protektor Ekstrak}

Sampel ditimbang sebanyak $100 \mathrm{mg}$ kemudian dimasukkan kedalam labu ukur 100 $\mathrm{ml}$ dan diencerkan dengan etanol, diperoleh larutan dengan konsentrasi 1000ppm. Dipipet sebanyak $15 \mathrm{ml}, 20 \mathrm{ml}, 25 \mathrm{ml}$ dilarutkan dalam labu ukur $50 \mathrm{ml}$ sehingga diperoleh larutan dengan konsentrasi 300ppm, 400ppm, 500 pm. Larutan yang telah diperoleh diukur dengan spektrofometer UV-Vis pada panjang gelombang 290-400 nm dengan menggunakan etanol sebagai blanko. Nilai serapan dicatat setiap interval $5 \mathrm{~nm}$ dari panjang gelombang 290 sampai $320 \mathrm{~nm}$ (tiga kali replikasi).

Tabel 1. Formula Krim Foto Protektor Ekstrak Etanol Buah Takokak

\begin{tabular}{lcc}
\hline \multicolumn{1}{c}{ Bahan } & Konsentrasi (\%) & Konsentrasi (Gram) \\
\hline Ekstrak buah takokak & 10 & 10 \\
Asam stearat & 12 & 12 \\
Setil alkohol & 2 & 2 \\
Trietanolamin & 2 & 2 \\
Gliserin & 8 & 8 \\
Metil paraben & 0,2 & 0,2 \\
Air suling & ad 100 & ad 100 \\
\hline
\end{tabular}

\section{Pembuatan Krim Ekstrak Etanol Buah Takokak}

Bahan yang terdapat dalam formula dipisahkan menjadi dua kelompok yaitu fase minyak dan fase air. Fase minyak terdiri dari asam stearat dan setil alkohol, sedangkan fase air TEA, gliserin, metil paraben, dan air. Dipanaskan fase minyak dan fase air hingga suhu yang sama sekitar $70^{\circ} \mathrm{C}-80^{\circ} \mathrm{C}$. Setelah semuanya melebur dan memiliki suhu yang sama, dimasukkan fase minyak ke dalam fase air lalu digerus dengan konstan hingga 
homogen dan terbentuk masa krim. Ekstrak daun ceremai yang telah ditimbang, dilarutkan dengan sedikit etanol $96 \%$ di dalam mortir, kemudian basis krim yang telah dibuat dimasukkan sedikit demi sedikit dan diaduk hingga homogen.

\section{Pengujian Mutu Fisik Sediaan Krim Foto Protektor}

Uji homogenitas dilakukan secara visual dengan mengoleskan sejumlah sediaan krim pada sekeping kaca atau bahan transparan lain yang cocok, sediaan harus menunjukkan susunan yang homogen dan tidak terlihat adanya butiran kasar (Elmitra, 2017).

Pengujian $\mathrm{pH}$ dilakukan dengan menggunakan $\mathrm{pH}$ indikator universal. 1 gram krim yang diuji dilarutkan dengan $10 \mathrm{~mL}$ air (perbandingan 1:10), kemudian kertas $\mathrm{pH}$ indikator universal dimasukkan ke dalam krim, lalu dicocokkan warna indikator dengan standar warna $\mathrm{pH}$ yang tertera pada wadahnya.

Penentuan tipe emulsi sediaan krim dilakukan dengan pengenceran fase, yaitu dengan mengencerkan 0,5 gram sediaan krim dengan $25 \mathrm{ml}$ air dalam beaker gelas, jika sediaan terdispersi secara homogen dalam air maka sediaan termasuk emulsi tipe m/a, sedangkan jika sediaan tidak terdispersi secara homogen dalam air maka sediaan termasuk emulsi tipe $\mathrm{a} / \mathrm{m}$.

Sampel krim dimasukkan ke dalam pot plastik, disimpan pada suhu kamar dan diukur parameter-parameter kestabilan seperti bau, warna, homogenitas dan $\mathrm{pH}$ dievaluasi selama penyimpanan 4 minggu dengan pengamatan setiap minggu pada suhu kamar.

\section{Uji Potensi Foto Protektor Krim}

Sampel ditimbang sebanyak 1 gram kemudian dimasukkan kedalam labu ukur 100 $\mathrm{ml}$ dan diencerkan dengan etanol 96\% sehingga diperoleh larutan sampel dengan konsentrasi 1000 ppm. Larutan diultrasonikasi selama 5 menit lalu disaring dengan kertas saring. Larutan filtrat kemudian diencerkan menjadi 100 ppm, 150 ppm, 200 ppm, 250 ppm, dan 300 ppm. Larutan yang telah diperoleh diukur dengan spektrofometer UVVis pada panjang gelombang 290-400 nm dengan menggunakan etanol $96 \%$ sebagai blanko. Nilai serapan dicatat setiap interval 5 $\mathrm{nm}$ (masing-masing konsentrasi dibuat triplo).

\section{Analisis Data}

Nilai Sun Protecting Factor (SPF) dihitung terlebih dahulu luas daerah di bawah kurva serapan (AUC) dari nilai serapan pada panjang gelombang 290 - $400 \mathrm{~nm}$ dengan interval 5 $\mathrm{nm}$, Nilai AUC dihitung menggunakan rumus berikut:

$$
[A U C] \frac{A a+A b}{2} x d P_{\text {a-b }}
$$

$\mathrm{Aa}=$ absorbansi pada panjang gelombang $\mathrm{a}$ $\mathrm{nm}$

$A b=$ absorbansi pada panjang gelombang $b$ $\mathrm{nm}$

$\mathrm{dPa}-\mathrm{b}=$ selisih panjang gelombang $\mathrm{a}$ dan $\mathrm{b}$

Nilai SPF masing-masing konsentrasi ditentukan menggunakan rumus berikut:

$$
\log S P F=\frac{A U C}{\lambda n-\lambda 1}
$$

$\lambda \mathrm{n}=$ panjang gelombang terbesar (dengan $A>0,01$ )

$\lambda 1=$ panjang gelombang terkecil $(290 \mathrm{~nm})$

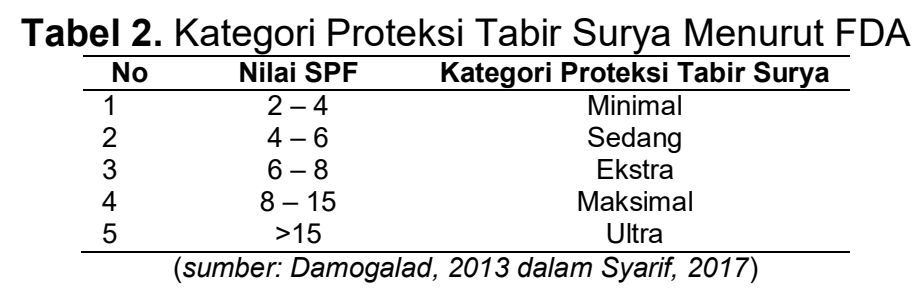

Data pengamatan nilai transmitan pada berbagai panjang gelombang dapat dihitung persen transmisi eritema dengan rumus sebagai berikut:\%Transmisi eritema

$$
\begin{aligned}
=\frac{E e}{\sum F e}=\frac{\sum(T \times F e)}{\sum F e} & \\
\text { dimana: } \mathrm{T} & =\text { Nilai transmisi } \\
\mathrm{Fe} & =\text { Fluks eritema } \\
\mathrm{Ee} & =\Sigma \mathrm{T} .
\end{aligned}
$$

$\mathrm{Fe}=$ banyaknya fluks eritema yang
diteruskan oleh ekstrak pada
panjang gelombang $295-320$
$\mathrm{~nm}$

Kemudian \%transmisi pigmentasi dihitung dengan rumus:

\%Transmisi pigmentasi $=\frac{E p}{\sum F p}=\frac{\sum(T \times F p)}{\sum F p}$

dimana: $T=$ nilai transmisi 
$\mathrm{Fp}=$ fluks pigmentasi

$\mathrm{Ep}=\Sigma \mathrm{T} . \mathrm{Fp}=$ banyaknya fluks pigmentasi yang diteruskan oleh ekstra pada panjang gelombang $325-375 \mathrm{~nm}$
$\Sigma \mathrm{Fp}=$ Jumlah total energi sinar UV yang menyebabkan pigmentasi.

Tabel 3. Klasifikasi Tabir Surya Berdasarkan Persentase Transmisi Transmisi Eritema dan Pigmentasi

\begin{tabular}{|c|c|c|}
\hline \multirow{2}{*}{ Kalsifikasi produk } & \multicolumn{2}{|c|}{$\begin{array}{c}\text { Persen transmisi sinar } \\
\text { ultraviolet }(\%)\end{array}$} \\
\hline & $\begin{array}{c}\text { Erythemal } \\
\text { Range }\end{array}$ & Taning Range \\
\hline Total block & $<1,0$ & $3-40$ \\
\hline Extra protection & $1-6$ & $42-86$ \\
\hline Regular suntan & $6-12$ & $45-86$ \\
\hline Fast taning & $10-18$ & $45-86$ \\
\hline
\end{tabular}

\section{HASIL DAN PEMBAHASAN}

Sediaan foto protektor merupakan sediaan kosmetik yang ditujukan untuk dapat mengurangi efek berbahaya dari paparan sinar ultraviolet. Molekul foto protektor bekerja dengan cara menyerap energi dari sinar UV, kemudian mengalami eksitasi dari ground state ketingkat energi yang lebih tinggi. Sewaktu molekul yang tereksitasi kembali ke kedudukan yang lebih rendah akan melepaskan energi yang lebih rendah dari energi semula yang diserap untuk menyebabkan eksitasi. Maka sinar UV dari energi yang lebih tinggi setelah diserap energinya oleh bahan kimia maka akan mempunyai energi yang lebih rendah. Sinar UV dengan energi yang lebih rendah akan kurang atau tidak menyebabkan efek sunburn pada kulit. Sinar UV dapat bedakan menjadi 3 kategori, yaitu UV-A pada panjang gelombang 320-400 nm, dimana pada panjang gelombang tersebut mempunyai efek radiasi pigmentasi berupa perubahan warna kulit menjadi kecoklatan, sinar UV-B pada panjang gelombang $290-320 \mathrm{~nm}$, dimana pada panjang gelombang tersebut dapat memberikan efek radiasi berupa eritema (kemerahan) serta sinar UV-C pada panjang gelombang 200-290nm, dimana hanya sinar UV-C yang tidak dapat menembus permukaan bumi karena telah diserap oleh ozon. Dengan demikian, penelitian ini hanya mengukur serapan ultraviolet pada panjang gelombang 290400nm.

Bahan alam yang digunakan sebagai target penelitian ini adalah buah takokak (Solanum torvum Swartz) yang diperoleh dari Desa Mungsengan, Kintamani Kabupaten Bangli. Buah takokak dilakukan ekstraksi dengan menggunakan metode maserasi dengan pelarut etanol $70 \%$. Metode ekstraksi dipilih karena merupakan metode ekstraksi yang sederhana dan minimal pemanasan. Etanol dipilih karena mempunyai daya ektraktif paling tinggi, minimal harus bersifat selektif dan dapat digunakan tidak hanya untuk ekstraksi klasik, tetapi dapat pula untuk ekstraksi tanaman yang berkhasiat atau bahan aktifnya belum diketahui dengan baik dan diinginkan ekstrak yang paling lengkap (Agoes, 2009). Ekstraksi dibuat dengan menggunakan 250gram serbuk simplisia buah takokak yang dimaserasi dengan 5 liter etanol dan dimaserasi dengan rotary evaporator pada suhu $40{ }^{\circ} \mathrm{C}-45^{\circ} \mathrm{C}$.

Hasil ekstraksi yang diperoleh berupa ekstrak kental dengan persentase rendemen sebesar 22,028\%. Hasil ekstraksi yang diperoleh diuji secara kualitatif untuk mengetahui keberadaan metabolit sekunder dari ekstrak tersebut. Ekstrak diuji dengan reaksi tabung dengan hasil positif mengandung flavonoid yang ditunjukan dengan terbentuknya warna kuning pada lapisan amil alkohol serta hasil positif tanin yang ditunjukan dengan terdapatnya endapan berwarna hijau.

Tabel 4. Hasil Skrining Flavonoid dan Tanin

\begin{tabular}{|c|c|c|c|c|}
\hline \multirow{3}{*}{$\begin{array}{c}\text { Uji } \\
\text { Flavonoid }\end{array}$} & \multirow{3}{*}{\begin{tabular}{l}
\multicolumn{2}{c}{ Parameter } \\
Terbentuk \\
warna merah, \\
kuning, jingga \\
pada lapisan \\
amil alkohol
\end{tabular}} & \multicolumn{2}{|c|}{ Hasil Uji } & \multirow{3}{*}{$\begin{array}{r}\text { Ket } \\
+ \\
+\end{array}$} \\
\hline & & \multirow{2}{*}{\multicolumn{2}{|c|}{$\begin{array}{lr}\text { Terbentuk } & \text { warna } \\
\text { kuning } & \text { pada } \\
\text { lapisan } & \text { amil } \\
\text { alkohol } & \end{array}$}} & \\
\hline & & & & \\
\hline Tanin & $\begin{array}{l}\text { Terdapat } \\
\text { endapan hijau } \\
\text { kehitaman }\end{array}$ & $\begin{array}{l}\text { Terdapat e } \\
\text { hijau }\end{array}$ & dapan & + \\
\hline
\end{tabular}

Ekstrak yang diperoleh kemudian dibuat dalam bentuk sediaan krim dengan konsentrasi sebesar 10\%. Bentuk sediaan krim dipilih karena krim merupakan pembawa dasar kosmetik yang dapat digunakan pada kulit atau selaput lendir untuk tujuan protektif, terapeutik 
atau profilaksis. Krim biasanya digunakan sebagai emolien atau pemakaian obat pada kulit. Keuntungan dari sediaan krim yaitu mudah menyebar rata pada permukaan kulit. Selain itu krim juga mudah dicuci dengan air, dan tidak lengket (Ansel HC, 2013). Stabilitas mutu fisik krim diukur selama 4 minggu dengan memperhatikan kestabilan homogenitas, $\mathrm{pH}$, tipe emulsi, warna dan bau.

Hasil pengukuran dari minggu ke-0 hingga minggu ke-4 tidak terjadi perubahan kestabilan, dimana sediaan yang diuji homogenitasnya dengan cara meletakkan sejumlah tertentu sediaan diatas sekeping kaca yang diamati tidak menunjukan adanya butiran-butian yang tidak terdispersi sehingga sediaan dianggap homogen, $\mathrm{pH}$ berada pada nilai 6 dimana pada $\mathrm{pH}$ tersebut termasuk kedalam pH kulit. Menurut Tranggono (2007) nilai $\mathrm{pH}$ sediaan harus mendekati nilai $\mathrm{pH}$ kulit yaitu 4,5-6,5. Nilai $\mathrm{pH}$ yang terlalu asam dapat mengiritasi kulit, sedangkan $\mathrm{pH}$ yang terlalu basa dapat menyebabkan kulit menjadi bersisik.

Tidak terjadinya perubahan warna yakni tetap berwarna coklat muda, tidak terjadi perubahan bau, dan tidak terjadi perubahan tipe emulsi. Pengujian tipe emulsi bertujuan untuk mengetahui tipe basis krim yang dibuat, selain itu penentuan tipe emulsi juga dapat digunakan sebagai parameter apakah krim yang dibuat stabil selama penyimpanan yang ditunjukan dengan tidak terjadinya perubahan fase emulsi. Hasil yang diperoleh yaitu sediaan terdispersi secara homogen dalam air maka dapat dikatakan bahwa sediaan termasuk emulsi tipe m/a.

Analisis penentuan potensi foto protektor ini dilakukan dengan menghitung nilai transmisi eritema (\%Te), tranmisi pigmentasi (\%Tp), dan Sun Protection Factor (SPF). Penentuan \%Te dan SPF adalah untuk menunjukkan efektivitas foto protektor terhadap sinar UV-B, sedangkan \%Tp ditentukan untuk melihat efektivitas tabir surya terhadap sinar UV-A.

Tabel 5. Nilai Rata-rata SPF Ekstrak

\begin{tabular}{cccc}
\hline \multirow{2}{*}{ Replikasi } & \multicolumn{3}{c}{ Nilai SPF Ekstrak } \\
\cline { 2 - 4 } & $\mathbf{3 0 0} \mathbf{~ p m}$ & $\mathbf{4 0 0} \mathbf{~ p p m}$ & $\mathbf{5 0 0} \mathbf{~ p m}$ \\
\hline I & 1,821 & 2,180 & 2,664 \\
II & 1,720 & 2,246 & 2,567 \\
III & 1,731 & 2,170 & 2,634 \\
SPF rata- & 1,757 & 2,199 & 2,615 \\
rata & - & Minimal & Minimal \\
Kategori & & & \\
\hline
\end{tabular}

Tabel 6. Nilai Rata-rata SPF Krim

\begin{tabular}{cccc}
\hline \multirow{2}{*}{ Replikasi } & $\mathbf{3 0 0} \mathbf{~ p p m}$ & $\mathbf{4 0 0} \mathbf{~ p m}$ & $\mathbf{5 0 0} \mathbf{~ p m}$ \\
\cline { 2 - 4 } & 1,642 & 1,884 & 2,150 \\
II & 1,659 & 2,020 & 2,047 \\
III & 1,680 & 1,936 & 2,158 \\
SPF rata- & 1,660 & 1,947 & 2,118 \\
rata & - & - & Minimal \\
Kategori & & &
\end{tabular}

Tabel 7. Hasil Uji Statistik Penurunan Nilai SPF Krim terhadap Ekstrak

\begin{tabular}{lcc} 
& Rerata & Nilai $\mathbf{p}$ \\
& & \\
\hline $\begin{array}{l}\text { Varian yang sama } \\
\text { diasumsikan }\end{array}$ & 2,1903 & 0,373 \\
$\begin{array}{l}\text { Varian yang sama tidak } \\
\text { diasumsikan }\end{array}$ & 1,9083 & 0,389 \\
\hline \multicolumn{2}{l}{ Keterangan: } & \\
$P>0,05$ maka ada perbedaan yang bermakna \\
$P<0,05$ maka tidak ada perbedaan yang bermakna
\end{tabular}

Tabel 8. Nilai Transmisi Eritema (\%Te) Ekstrak

\begin{tabular}{cccc}
\hline \multirow{2}{*}{ Replikasi } & \multicolumn{3}{c}{ Nilai Transmisi Eritema (\%Te) } \\
\cline { 2 - 4 } & $\mathbf{3 0 0} \mathbf{~ p p m}$ & $\mathbf{4 0 0} \mathbf{~ p p m}$ & $\mathbf{5 0 0} \mathbf{~ p p m}$ \\
\hline I & $38,6 \%$ & $30,2 \%$ & $22,2 \%$ \\
II & $48,1 \%$ & $33,0 \%$ & $33,7 \%$ \\
III & $44,6 \%$ & $30,5 \%$ & $22,1 \%$ \\
$\begin{array}{c}\text { \%Te rata- } \\
\text { rata }\end{array}$ & $43,7 \%$ & $31,2 \%$ & $26 \%$ \\
Kategori & - & - & - \\
\hline
\end{tabular}

Tabel 9. Nilai Transmisi Pigmentasi (\%Tp) Ekstrak

\begin{tabular}{cccc}
\hline \multirow{2}{*}{ Replikasi } & \multicolumn{3}{c}{ Nilai Transmisi Pigmentasi (\%Tp) } \\
\cline { 2 - 4 } & $\mathbf{3 0 0} \mathbf{~ p p m}$ & $\mathbf{4 0 0} \mathbf{~ p p m}$ & $\mathbf{5 0 0} \mathbf{~ p p m}$ \\
\hline I & $56,5 \%$ & $47,8 \%$ & $40,2 \%$ \\
II & $58,0 \%$ & $50,2 \%$ & $49,7 \%$ \\
III & $57,6 \%$ & $47,8 \%$ & $40,5 \%$ \\
$\begin{array}{c}\text { \%Tp rata- } \\
\text { rata }\end{array}$ & $57,4 \%$ & $48,6 \%$ & $43,5 \%$ \\
Kategori & $\begin{array}{c}\text { Extra } \\
\text { protection }\end{array}$ & $\begin{array}{c}\text { Extra } \\
\text { protection }\end{array}$ & protection \\
\hline
\end{tabular}

Tabel 10. Nilai Transmisi Pigmentasi (\%Tp) Krim

\begin{tabular}{cccc}
\hline \multirow{2}{*}{ Replikasi } & \multicolumn{2}{c}{ Nilai Transmisi Pigmentasi (\%Tp) } \\
\cline { 2 - 4 } & $\mathbf{3 0 0} \mathbf{~ p p m}$ & $\mathbf{4 0 0} \mathbf{~ p p m}$ & $\mathbf{5 0 0} \mathbf{~ p p m}$ \\
\hline I & $61,4 \%$ & $53,8 \%$ & $48,0 \%$ \\
II & $60,8 \%$ & $40,3 \%$ & $49,7 \%$ \\
III & $60,0 \%$ & $52,4 \%$ & $47,2 \%$
\end{tabular}




\begin{tabular}{cccc}
$\begin{array}{c}\text { \%Tp rata- } \\
\text { rata }\end{array}$ & $60,7 \%$ & $48,8 \%$ & $48,3 \%$ \\
Kategori & $\begin{array}{c}\text { Extra } \\
\text { protection }\end{array}$ & $\begin{array}{c}\text { Extra } \\
\text { protection }\end{array}$ & $\begin{array}{c}\text { Extra } \\
\text { protection }\end{array}$ \\
\hline
\end{tabular}

Ekstrak yang telah diuji secara kualitatif diukur potensi foto proteksinya pada spektrofotometer dengan konsentrasi 300, 400 dan 500 ppm. Ekstrak dilarutkan pada larutan blanko kemudian diukur pada panjang gelombang setiap $5 \mathrm{~nm}$. Absorbansi yang diperoleh kemudian dihitung nilai SPFnya serta persentase eritema dan pigmentasi. Nilai ratarata SPF ekstrak buah takokak pada konsentrasi 300 ppm sebesar 1,757; konsentrasi 400 ppm sebesar 2,199; konsentrasi 500 ppm sebesar 2,118.

Konsentrasi $300 \mathrm{ppm}$ tidak dapat dikategorikan sebagai tabir surya karena memiliki nilai SPF $<2$, pada konsentrasi 400 ppm dan 500 ppm dikategorikan sebagai tabir surya minimal karena berada pada rentang nilai 2-4. Nilai SPF menunjukkan seberapa lama suatu produk mampu melindungi atau memblok sinar UV yang dapat menyebabkan kulit menjadi terbakar. Sebagai salah satu contoh, pada konsentrasi ekstrak 500 ppm diperoleh SPF sebesar 2,118, dimana nilai tersebut dapat diartikan jika ekstrak tersebut mampu melindungi kulit dari sinar UV sebanyak 2,118 kali lebih lama dibandingkan jika tanpa menggunakan ekstrak tersebut.

Penentuan potensi foto protektor dilakukan secara in vitro dengan spektrofotometer pada panjang gelombang 290-400nm. Krim dilarutkan ke dalam larutan blanko hingga diperoleh konsentrasi sebesar 1000ppm. Larutan induk tersebut kemudian diencerkan hingga diperoleh sampel pada konsentrasi 300, 400 dan 500 ppm. Masingmasing sampel dibuat 3 kali pengulangan. Diukur nilai absorbansi tiap panjang gelombang $5 \mathrm{~nm}$. Dihitung nilai SPF serta persentase eritema dan pigmentasi dari masing-masing konsentrasi sampel.

Dari hasil penelitian yang sudah dilaksanakan diperoleh nilai rata-rata SPF krim foto protektor pada konsentrasi 300 ppm, 400 ppm dan 500 ppm secara berturut-turut adalah 1,$660 ; 1,947$ dan 2,118. Dari ketiga konsentrasi tersebut, hanya konsentrasi 500 ppm yang memenuhi kategori sebagai foto protektor minimal (berada pada rentang 2-4), sedangkan pada konsentrasi 300 ppm dan 400 ppm berada <2. Persentase penurunan nilai SPF dari ekstrak buah takokak dengan sediaan krim yang telah dibuat sebesar 5-19\%. Hasil analisis Independent t-test menunjukan nilai signifikansi $p=0,373$. Hal ini menunjukan bahwa tidak terdapat perbedaan bermakna antara nilai SPF ekstrak buah takokak dengan nilai SPF krim foto protektor ekstrak buah takokak. Tidak adanya perbedaan yang bermakna antara ekstrak dengan sediaan menunjukan bahwa basis yang digunakan untuk membuat sediaan tidak mempengaruhi kemampuan foto proteksi dari ekstrak.

Persentase eritema dinyatakan sebagai persen total fluks eritema yang diteruskan oleh bahan tabir surya. Semakin kecil suatu persen transmisi eritema dan pigmentasi suatu sediaan berarti semakin sedikit sinar UV yang diteruskan sehingga dapat dikatakan bahwa sediaan tersebut memilki aktifitas yang besar sebagai foto protektor. Dari hasil penelitian yang telah dilaksanakan, diperoleh persentase transmisi eritema yang besar, persentase transmisi eritema ekstrak buah takokak pada panjang gelombang 300 ppm sebesar $43,7 \%$, panjang gelombang 400 ppm sebesar $31,2 \%$ dan pada panjang gelombang 500 ppm sebesar $26 \%$. Persentase transmisi eritema krim ekstrak buah takokak pada konsentrasi 300 ppm adalah sebesar 41,8\%, pada konsentrasi 400 ppm sebesar $36,9 \%$ dan pada konsentrasi 500 ppm sebesar $31,8 \%$. Persentase eritema tersebut cukup besar sehingga baik ekstrak maupun krim ekstrak buah takokak tidak memenuhi kategori. Hal tersebut artinya ekstrak dan sediaan pada konsentrasi 300 ppm, 400 ppm dan 500 ppm tidak mampu untuk menyerap ataupun memantulkan sinar UV-B sehingga pada penggunaannya dapat menimbulkan eritema.

Persentase transmisi pigmentasi ekstrak buah takokak pada konsentrasi 300 ppm sebesar $57,4 \%$, pada konsentrasi 400 ppm sebesar $48,6 \%$ serta pada konsentrasi 500 ppm sebesar $43,5 \%$. Dari ketiga konsentrasi tersebut, transmisi pigmentasi dikriteriakan sebagai "extra protection" karena berada pada rentang kategori 42-86. Kategori tersebut dapat diartikan bahwa ekstrak buah takokak memiliki kemampuan untuk menyerap sinar UV-A tetapi masih dapat menyebabkan kecoklatan (tanning) pada kulit yang bersifat sementara.

Persentase transmisi pigmentasi krim foto protektor ekstrak buah takokak pada konsentrasi 300 ppm sebesar $60,7 \%$, pada konsentrasi $400 \mathrm{ppm}$ sebesar $48,8 \%$ dan konsentrasi 500 ppm sebesar 48,3\%. Ketiga 
konsentrasi tersebut dapat dikategorikan sebagai transmisi pigmentasi "extra protection". Sediaan tersebut mampu untuk menyerap sinar UV-A tetapi masih dapat dapat menyebabkan kulit kecoklatan (tanning) sementara.

Secara keseluruhan tidak ada perbedaan yang signifikan antara ekstrak buah takokak dengan krim foto protektor ekstrak buah takokak baik dari segi nilai SPF maupun persentase transmisi eritema dan transmisi pigmentasinya. Ekstrak buah takokak hanya mampu menghasilkan SPF minimal dengan kemampuan transmisi pigmentasi extra protection, sedangkan sediaan krim foto protektor ekstrak buah takokak juga hanya dapat menghasilkan SPF minimal dengan kemampuan transmisi pigmentasi extra protection. Dengan demikian, formulasi krim ekstrak buah takokak tidak berpengaruh secara signifikan terhadap kemampuan potensi foto protektor ekstrak etanol buah takokak.

\section{KESIMPULAN}

Berdasarkan hasil penelitian yang telah dilaksanakan dapat disimpulkan bahwa:

1. Potensi foto protektor ekstrak buah takokak dilihat dari rata-rata nilai SPF sebesar sebesar 1,757 pada konsentrasi $300 \mathrm{ppm}$, sebesar 2,199 pada konsentrasi 400ppm dan sebesar 2,615 pada konsentrasi $500 \mathrm{ppm}$ dan sediaan krim ekstrak etanol buah takokak memiliki ratarata nilai SPF sebesar 1,660 pada konsentrasi $300 \mathrm{ppm}, \quad 1,947$ pada konsentrasi 400ppm dan 2,118 pada konsentrasi 500ppm. Berdasarkan \%Te pada konsentrasi 300 ppm, 400 ppm dan 500 ppm baik ekstrak maupun krim dengan ekstrak buah takokak belum dapat memberikan perlindungan terhadap kulit dari eritema. Berdasarkan nilai rata-rata $\%$ Tp pada konsentrasi $300 \mathrm{ppm}$ hingga 500 ppm baik ekstrak maupun krim ekstrak buah takokak mampu memberikan perlindungan "extra protection" terhadap paparan sinar UV-A.

2. Secara keseluruhan tidak terdapat perbedaan yang bermakna antara rata- rata nilai SPF ekstrak dengan rata-rata nilai SPF krim ekstrak buah takokak.

\section{DAFTAR PUSTAKA}

Cairns, Donald. 2008. Intisari Kimia Farmasi Edisi. Jakarta: Penerbit Buku Kedokteran EGC.

Donglikar, Mukund Manikrao, and Sharada Laxman Deore. 2016. Sunscreens: A Review. Pharmacogn. J. 50(3): 221-24.

Hamsidi, Rini, Nurlena Ikawati, and Ahmad Zaeni. 2014. Uji Aktivitas Tabir Surya Formula Sediaan Losio Ekstrak Metanol Daun Mangkokan ( Nothophanax Scutellarium Merr .). 2(1): 126-30.

Hidayati, Nur Laili Dwi, And Tita Nofianti. 2014. Penelusuran Potensi Antifertilitas Buah Takokak (Solanum Torvum Swartz) Melalui Skrining Fitokimia Dan Pengaruhnya Terhadap Siklus Estrus Tikus Putih (Rattus Norvegicus). Jurnal Kesehatan Bakti Tunas Husada Volume 11 11(1): 94-103.

Ismail, Isriany. 2013. Potensi Bahan Alam Sebagai Bahan Aktif Kosmetik Tabir Surya. Jf Uinam 1(1): 45-55.

Kulkarni, Snehal.S, Rasika DBhalke, Vishal.V Pande, and Prakash.N Kendre. 2014. Herbal Plants In Photo Protection And Sun Screening Action: An Overview. Indo American Journal of Pharmaceutical Research 4(02).

Syarif, ST. Umrah. 2017. Uji Potensi Tabir Surya Ekstrak Daun Jambu Biji (Psidium guajava L). Makasar: Universitas Alauddin Makasar

Whenny, Rolan Rusli, and Laode Rijai. 2016. Aktivitas Tabir Surya Ekstrak Daun Cempedak ( Artocarpus Champeden Spreng ). (December 2015).

Yasin, Rif'atul Adilah. 2017. Uji Potensi Tabir Surya Ekstrak Kulit Buah Jeruk Nipis (Citrus Aurantifolia) Secara In Vitro. 88.

Yousaf, Zubaida, Ying Wang, and Elias Baydoun. 2013. Phytochemistry and Pharmacological Studies on Solanum Torvum. 3(04): 152-60. 